\title{
Regresi Median Pada Copula Bivariat
}

\author{
${ }^{1}$ Geraldus Anggoro Rinadi, ${ }^{2}$ Leopoldus Ricky Sasongko, ${ }^{3}$ Bambang Susanto \\ ${ }^{1,2,3}$ Pendidikan Matematika, Universitas Kristen Satya Wacana Salatiga, Salatiga \\ 1662015010@student.uksw.edu, ${ }^{2}$ leopoldus.sasongko@staff.uksw.edu, ${ }^{3}$ bambang.susanto@staff.uksw.edu
}

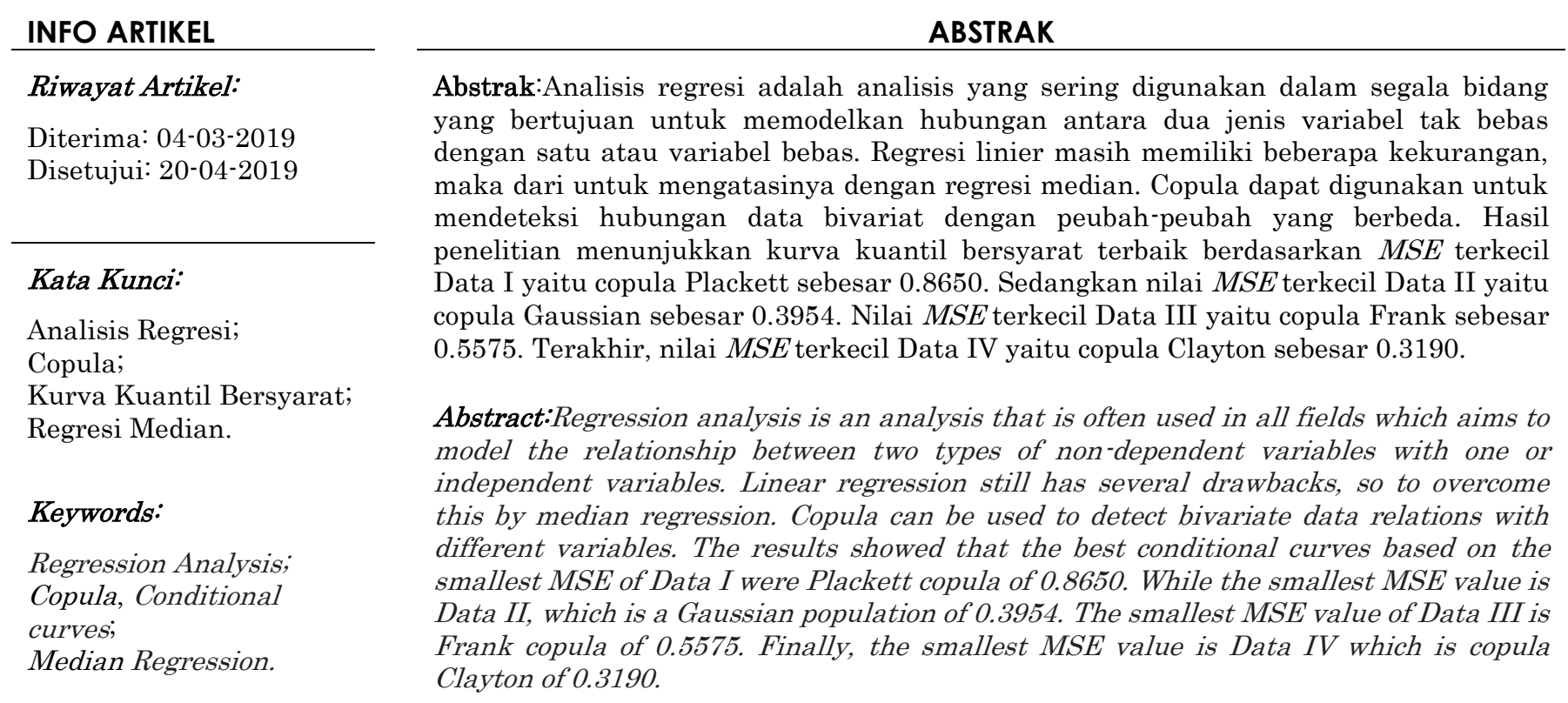

\section{A. LATAR BELAKANG}

Analisis yang dapat digunakan untuk mempelajari keterhubungan antar dua peubah acak adalah analisis regresi, salah satu regresi yang dikenal adalah regresi linier.Salah satu kegunaan regresi linier adalah untuk melakukan prediksi di nilai-nilai tertentu berdasarkan data-data yang dimiliki.Hubungan di antara peubah-peubah dalam model regresi linier dinyatakan dalam fungsi linier. Dengan kata lain, dalam regresi linier, keterhubungan antar dua peubah acak digambarkan oleh garis linier yang merupakan fungsi linier peubah satu terhadap yang lain.

Syarat perlu yang ada dalam regresi linier adalah (a) data dan error meng-ikuti distribusi Normal (Gaussian), (b) variansi error konstan (homoskedastisitas), (c) tidak ada multikolinieritas, (d) tidak ada autokorelasi pada data(Uthami IAP, 2013) yang mana beberapa syarat tersebut muncul sebagai akibat penerapan model distribusi bivariat
Normal untuk dua peubah acak yang diregresikan (Bertsekas DP, 2008). Karena syarat tersebut, metode lain yang dapat digunakan untuk analisis keterhubungan dua peubah acak dibutuhkan guna menjadi metode alternatif jika syarat perlu dalam regresi linier tidak terpenuhi, seperti error tidak berdistribusi Normal atau variansi error tak konstan (heteroskedastisitas).

Penelitian ini membahas metode alternatif yang dapat digunakan untuk analisis keterhubungan antar dua peubah acak melalui regresi median yang mana dalam hal ini diperoleh dengan melibatkan distribusi bivariat yang disebut copula.Copula merupakan suatu fungsi distribusi bivariat yang khusus dan unik.Suatu fungsi distribusi bivariat dapat dibentuk dari suatu copula sebagai akibat dari Teorema Sklar (Nelsen, 2006). Menurut Tse (2009), teorema Sklar menawarkan copula sebagai solusi perolehan suatu fungsi distribusi bivariat yang memiliki ke-lebihan yaitu (a) perolehan banyak pilihan fungsi distribusi bivariat melalui copula, (b) dapat membentuk fungsi 
distribusi bivariat dengan marginal-marginal dari keluarga distribusi yang tidak perlu sama, dan (c) copula dapat menggambarkan berbagai macam keterhubungan antar dua peubah acak dengan jelas. Fungsi copula yang dibahas pada penelitian ini adalah copula Gaussian, copula Frank, copula Clayton, dan copula Plackett. Keunggulan lain dari copula adalah bahwa copula tidak ketat terhadap asumsi sebaran berdistribusi tertentu, dapat menjelaskan hubungan tak linier, mudah membangun sebaran bersamanya melalui marginal dari peubah acak yang tidak perlu berasal dari keluarga distibusi yang sama.

Adapun dalam penelitian ini membahas kurva kuantil median yang selanjut-nya disebut regresi median pada copula-copula yang telah disebutkan. Regresi median dari suatu copula bivariat, yang diperoleh dari kurva kuantil bersyarat pada kuantil median, mampu menganalisis keterhubungan dua peubah acak yang tidak linier sehingga cakupan analisis keterhubungan dua peubah acak menjadi lebih luas, tidak hanya berkisar pada keterhubungan yang linier.

\section{B. TINJAUAN PUSTAKA}

1. Copula

Copula (bivariat) adalah suatu fungsi distribusi bivariat dengan marginal-marginalnya berdistribusi seragam di $[0,1]$. Suatu copula $C$ dinyatakan oleh

$$
C(u, v)=\operatorname{Pr}[U \leq u, V \leq v](1)
$$

untuk peubah acak $U$ dan $V$ yang masing-masing berdistribusi seragam di $[0,1]$.Menurut teorema Sklar (Nelsen, 2006), fungsi distribusi bivariat $X$ dan $Y$ dapat dinyatakan oleh

$$
\begin{aligned}
& H(x, y)=P_{r}[X \leq x, Y \leq y] \\
& =P_{r}[F(X) \leq F(x), G(Y) \leq G(y)] \\
& P_{r}(F(X) \leq u, G(Y) \leq v)=P_{r}[U \leq u, V \leq v] \\
& =C(u, v)
\end{aligned}
$$

untuk suatu copula $C$.

\section{Koefisien Korelasi Pearson dari Dua Peubah Acak}

Korelasi Pearson (Pearson rank correlation) adalah ukuran keterhubungan linier dua peubah. Ukuran keterhubungan ini biasanya dinotasikan oleh $r$. Untuk dua peubah acak bivariat $(X, Y)$, memiliki titik sampel sebanyak $n$ yaitu $\left(x_{1}, y_{1}\right),\left(x_{2}, y_{2}\right)$, $\left(x_{3}, y_{3}\right) \ldots,\left(x_{n}, y_{n}\right)$, korelasi Pearson dihitung oleh

$r=\frac{\operatorname{Cov}(X, Y)}{\sqrt{\operatorname{Var}[X] \operatorname{Var}[Y]}}$

$$
=\frac{n \sum_{i=1}^{n} x_{i} y_{i}-\sum_{i=1}^{n} x_{i} \sum_{i=1}^{n} y_{i}}{\sqrt{n \sum_{i=1}^{n} x_{i}^{2}-\left(\sum_{i=1}^{n} x_{i}\right)^{2}} \sqrt{n \sum_{i=1}^{n} y_{i}^{2}-\left(\sum_{i=1}^{n} y\right)^{2}}} \text { (3) }
$$

\section{Kendall's Tau dari Dua Peubah Acak dan Suatu Copula $C$}

Menurut Nelsen (2006), Kendall's tau untuk $X$ dan $Y$ dalam kaitannya dengan suatu copula $C$ dan berdasarkan persamaan (2.5) dimana $I^{2}$ merupakan interval $(0,1) \times(0,1)$ adalah

$$
\tau=4 \iint_{I^{2}} C(u, v) d C(u, v)-1
$$

\section{Spearman's Rho}

Berdasarkan Nelsen (2006), Spearman's rho untuk $X$ dan $Y$ dalam kaitannya dengan suatu copula $C$ dan berdasarkan persamaan (2.7) adalah

$$
\rho=12 \iint_{I^{2}} C(u, v) d u d v
$$

Fungsi densitas peluang $Y=y$ bersyarat $X=x$ yaitu $k(y \mid x)$ dan dalam kaitannya dengan copula adalah

$$
\begin{gathered}
k(y \mid x)=\operatorname{Pr}[Y \leq y \mid X=x]=\operatorname{Pr} \frac{[X=x, Y=y]}{\operatorname{Pr}[X=x]} \\
=\frac{h(x, y)}{f(x)}=\frac{c(F(x), G(y)) f(x) g(y)}{f(x)} \\
=c(F(x), G(y)) g(y)(6)
\end{gathered}
$$

lalu fungsi distribusi $Y$ bersyarat $X=x$ yaitu $K(y \mid x)$ dan dalam kaitannya dengan copula diperoleh dari

$$
\begin{gathered}
K(y \mid x)=\operatorname{Pr}[Y \leq y \mid X=x] \\
=\int_{-\infty}^{y} k(y \mid x) d y=\int_{-\infty}^{y} c(F(x), G(y)) g(y) d y \\
=\frac{\partial C(F(x), G(y))}{\partial F(x)}(7)
\end{gathered}
$$

\section{Simulasi Pembangkitan Bilangan Acak Bivariat Menggunakan Copula (Sasongko, 2014)}

Pembangkitan bilangan acak bivariat $\{(x, y)\}$ dari suatu fungsi distribusi bivariat $H$ bukan suatu hal yang mudah karena bilangan acak bivariat tersebut harus dibangkitkan secara bersama-sama.

Prosedur untuk membangkitkan bilangan acak bivariat $\{(x, y)\}$ dari suatu fungsi distribusi bivariat $H$ dengan menggunakan copula berdasarkan persamaan (1.7). terlebih dahulu pandang bahwa fungsi $\frac{\partial C(u, v)}{\partial u}$ adalah fungsi dalam $v$, misal $u=F(x)$ dan $v=G(y)$, maka 


$$
Z_{u}=\frac{\partial C(u, v)}{\partial u}(8)
$$

\section{Parametric Bootstrap untukUkuran Statistik Cramer-von Mises Guna Uji Kecocokan Copula (Sasongko, 2014)}

Ukuran statistik dan p-valueCramer-von Mises $\left(S_{n}\right)$ dapat diperoleh melalui metode simulasi parametric bootstrap. Algoritma simulasi Parametric Bootstrap tersebut dijabarkan sebagai berikut:

Diketahui data bivariat sebanyak $n$ pasang yaitu $\left\{\left(x_{a}, y_{a}\right)\right\}, a=0,1,2,3, \ldots n$. Untuk $N$ bilangan bulat positif sangat besar,

1 Bangkitkan $n$ sampel acak bivariat $\left\{\left(x_{i}, y_{i}\right)\right\}$, $i=0,1,2,3 \ldots n$, dari suatu distribusi bivariat $H_{\theta}(x, y)$ atau Copula $C_{\theta}(F(x), G(y))$.

2 Hitung fungsi

$H_{e}\left(x_{1}, y_{1}\right)=C_{e}\left(F\left(x_{i}\right), G\left(y_{i}\right)\right)=$ $\frac{\#\left(x_{a} \leq x_{i}, y_{a} \leq y_{i}\right)}{n+1}$ yang mana $\#\left(x_{a} \leq x_{i}, y_{a} \leq y_{i}\right)$ menyatakan banyak data bivariat $\left\{\left(x_{a}, y_{a}\right)\right\}$ dengan $x_{a} \leq x_{i}$ dan $y_{a} \leq y_{i}$,

3 Untuk $j=1$, hitung

$$
\begin{aligned}
s_{n, j}^{*} & =\sum_{i=1}^{n}\left[H_{e}\left(x_{i}, y_{i}\right)-H_{\theta}\left(x_{i}, y_{i}\right)\right]^{2} \\
& =\sum_{i=1}^{n}\left[C_{e}\left(F\left(x_{i}\right), G\left(y_{i}\right)\right)-C_{\theta}\left(F\left(x_{i}\right), G\left(y_{i}\right)\right)\right]^{2}
\end{aligned}
$$

4 Untuk $j=j+1$, ulangi poin 1 sampai poin 3 , ke poin 5 jika $j=N+1$,

5 Hitung $p$-value yaitu $\frac{\#\left(s_{n, j}^{*}<s_{n}\right)}{N}$ atau $\sum_{j=1}^{N}\left(\frac{I\left(s_{n, j}^{*}<s_{n}\right)}{N}\right)$, yang mana $I\left(s_{n, j}^{*}<s_{n}\right)$ adalah fungsi bernilai 1 untuk $s_{n, j}^{*}<s_{n}$ dan 0 untuk lainnya.

Parameter pada nomor 3, baik fungsi di ruas kiri atau kanan, dapat diperoleh berdasarkan kaitannya dengan ukuran keterhubungan (korelasi Pearson, Kendall, atau Spearman) pada data.Uji kecocokan data bivariat terhadap suatu distribusi bivariat atau fungsi copula dapat dilakukan berdasarkan statistik Cram é $r$ von Misses dengan dibantu simulasi parametric bootstrap seperti yang telah dijelaskan.

\section{Regresi Median}

Misalkan $\hat{y}_{\alpha}(x)$ merupakan suatu fungsi dari solusi penyelesaian pada

$$
K(y \mid x)=\operatorname{Pr}[Y \leq y \mid X=x]=\alpha
$$

untuk kuantil $0<\alpha<1$, maka $\hat{y}_{\alpha}(x)$ adalah kurva kuantil $\alpha, Y$ bersyarat $X=x$.Fungsi $K(y \mid x)$ diperoleh melalui suatu distribusi bivariat dengan $H(x, y)$.
Fungsi $H(x, y)$ dapat diestimasi dari fungsi distribusi bivariat yang diketahui/dikenal atau melalui copula, yang mana kaitannya dengan copula dinyatakan oleh persamaan (1.1). Fungsi $K(y \mid x)$ dapat diperoleh melalui

$$
K(y \mid x)=\frac{\partial H(x, y)}{\partial x}=\frac{\partial C(F(x), G(y))}{\partial F(x)}(10)
$$

\section{Copula Gaussian}

Bentuk umum dari Copula Gaussian adalah

$$
C_{G}(u, v)=\Phi_{\rho}\left(\Phi^{-1}(u), \Phi^{-1}(v)\right)(11)
$$

Fungsi properti bersyarat dari Copula Gaussian ditunjukkan oleh

$$
\frac{\partial C_{G}(u, v)}{\partial u}=\Phi\left(\frac{\Phi^{-1}(v)-\rho \Phi^{-1}(u)}{\sqrt{1-\rho^{2}}}\right)
$$

Sedangkan kurva kuantil bersyarat dari Copula Gaussian adalah sebagai berikut (Bernard dan Czado, 2014)

$$
\hat{v}_{\alpha}(u)=\Phi\left(\Phi^{-1}(\alpha) \sqrt{1-\rho^{2}}+\rho \Phi^{-1}(u)\right)
$$

Regresi mediannya adalah

$$
\hat{y}_{1 / 2}(x)=G^{-1}\left(\Phi\left(\rho \Phi^{-1}(F(x))\right)\right)
$$

\section{Copula Frank}

Bentuk umum copula Frank adalah (Nelsen, 2006)

$$
C_{F, \theta}(u, v)=-\frac{1}{\theta} \ln \left(1+\frac{\left(e^{-\theta u}-1\right)\left(e^{-\theta v}-1\right)}{e^{-\theta}-1}\right)
$$

Dengan fungsi properti bersyarat copula Frank memiliki bentuk sebagai berikut

$\frac{\partial C_{F, \theta}(u, v)}{\partial u}=\frac{e^{-\theta u}\left(1-e^{-\theta v}\right)}{-e^{-\theta}-e^{-\theta(u+v)}+e^{-\theta u}+e^{-\theta v}}$

Fungsi kurva kuantil bersyarat dari copula Frank memiliki bentuk sebagai berikut (Bernard dan Czado, 2014)

$\hat{v}_{\alpha}(u)=-\frac{1}{\theta} \ln \left(1-\frac{\alpha\left(1-e^{-\theta}\right)}{e^{-\theta u}+\alpha\left(1-e^{-\theta u}\right)}\right)$

Regresi mediannya adalah

$$
\hat{y}_{1 / 2}(x)=G^{-1}\left(-\frac{1}{\theta} \ln \left(1-\frac{1-e^{-\theta}}{1+e^{-\theta F(x)}}\right)\right)
$$

Selanjutnya persamaan Kendall's tau dari copula Frank dinyatakan oleh

$$
\tau=1-\frac{4\left(1-D_{1}\left(\theta_{F}\right)\right)}{\theta_{F}}(19)
$$




\section{Copula Clayton}

Bentuk umum dari copula Clayton adalah (Nelsen, 2006)

$$
C_{C, \theta}(u, v)=\max \left\{\left(u^{-\theta} t v^{-\theta}-1\right)^{\frac{-1}{\theta}}, 0\right\}(20)
$$

Fungsi properti bersyarat copula Clayton memiliki bentuk sebagai berikut

$$
\frac{\partial C_{C, \theta}(u, v)}{\partial u}=\left(u^{-\theta}+v^{-\theta}-1\right)^{\frac{-1}{\theta}-1} u^{-\theta-1}
$$

Fungsi kurva kuantil bersyarat dari copula Clayton memiliki bentuk sebagai berikut (Bernard dan Czado, 2014)

$$
\hat{v}_{\alpha}(u)=\left(\left(\alpha^{\frac{-\theta}{1+\theta}}-1\right) u^{-\theta}+1\right)^{\frac{-1}{\theta}}
$$

Regresi mediannya adalah

$$
\hat{y}_{1 / 2}(x)=G^{-1}\left(\left(2^{\frac{\theta}{1+\theta}}-1\right) F(x)^{-\theta}+1\right)^{\frac{-1}{\theta}}
$$

Selanjutnya persamaan Kendall's tau dari copula Clayton dinyatakan oleh

$$
\tau=\frac{\theta}{\theta+2}(24)
$$

\section{Copula Plackett}

Copula Plackett memiliki bentuk umum yang dapat didefinisikan sebagai berikut (Nelsen, 2006)

$$
\begin{aligned}
& C_{P, \theta}(u, v) \\
& =\frac{[1+(\theta-1)(u+v)]-\sqrt{[1+(\theta-1)(u+v)]^{2}-4 u v \theta(\theta-1)}}{2(\theta-1)}
\end{aligned}
$$

Fungsi bersyarat copula Plackett mempunyai bentuk sebagai berikut:

$$
\frac{\partial C_{P, \theta}(u v)}{\partial u}=\frac{\theta v+(1-\theta) C(u, v)}{1+(\theta-1)[u+v-2 C(u, v)]} \text { (25) }
$$

Sedangkan fungsi kurva kuantil bersyarat dari copula Plackett adalah sebagai berikut (Bernard dan Czado, 2014)

$$
\hat{v}_{\alpha}(u)=\frac{\alpha+(1-\theta)\left[(2 \alpha-1) C_{P}\left(u, \hat{v}_{\alpha}(u)\right)-\alpha u\right]}{\alpha+\theta-\alpha \theta}(26)
$$

\section{Regresi mediannya adalah}

$$
\hat{y}_{1 / 2}(x)=G^{-1}\left(\frac{1-(1-\theta) F(x)}{1+\theta}\right)
$$

Berdasarkan Nelsen (2006), diperoleh Spearman's rho melalui copula Plackett dinyatakan oleh

$$
\rho=\frac{\theta+1}{\theta-1}-\frac{2 \theta}{(\theta-1)^{2}} \ln \theta
$$

\section{Validasi Kurva Regresi Median}

Dalam menentukan kesalahan tersebut dapat kita ukur dengan menggunakan ukuran error. Dalam penelitian ini, error diukur melalui Mean Square Error (MSE) yangdapat dihitung dengan persamaan:

$$
\operatorname{MSE}(\hat{y})=\frac{1}{n} \sum_{i=1}^{n}\left(\hat{y}_{t}-y_{t}\right)^{2}(29)
$$

\section{METODE PENELITIAN}

\section{Studi Pustaka}

Langkah pertama yang dilakukan penulis adalah melakukan studi pustaka dengan mencari referensi teori dan penelitian terdahulu yang berhubungan.Referensi diperoleh dari berbagai sumber seperti makalah jurnal, prosiding, dan pustaka lainnya.

\section{Simulasi Data}

Data yang digunakan dalam penelitian ini adalah data simulasi yang diperoleh melalui Program R. Data tersebut dibangkitkan untuk selanjutnya dilakukan analisis-analisis dan pengujian dalam penelitian.Banyak data yang dibangkitkan adalah 100 (seribu) untuk tiap copula yang dibahas dalam penelitian yaitu copula Gaussian, Frank, Clayton, dan Plackett.

\section{Pengolahan Data}

Pengolahan data dilakukan sebagai berikut:

a. Data simulasi diperoleh dari pembangkitan bilangan acak bivariat pada setiap copula dengan marginal-marginal normal baku.

b. Data terbagi dalam empat yaitu Data I hingga Data IV yang akan dianalisis.

c. Mengukur keterhubungan data yang sudah dibangkitkan dengan mengguna-kan Kendall's Tau, Spearman's Rho, dan korelasi Pearson.

Pengolahan data bertujuan untuk mempermudah dalam melakukan analisis data.

\section{Analisis Data}

Setelah pengolahan data dilakukan analisis data dengan langkah-langkah sebagai berikut:

a. Menggambarkan dan melakukan analisis sederhana dengan menghitung korelasi pada Data I yang dipasangkan secara bivariat.

b. Estimasi parameter model distribusi bivariat atau copula berdasarkan korelasi Kendall's Tau, Spearman's Rho, dan korelasi Pearson.

1) Estimasi parameter $\rho$ dari copula Gaussian diperoleh dari persamaan (3). 
2) Estimasi parameter $\theta$ dari copula Frank diperoleh dari persamaan (19) secara numerik.

3) Estimasi parameter $\theta$ dari copula Clayton diperoleh dari persamaan (24).

4) Estimasi parameter $\theta$ dari copula Plackett diperoleh dari persamaan (28) pada secara numerik.

c. Uji kecocokan data bivariat (Data I) terhadap model distribusi bivariat atau copula untuk mencari nilai $S_{n}$ dan $p_{\text {value }}$ berdasarkan statistik uji Cramér von Misses dan dibantu dengan simulasi parametrik bootstrap.

d. Mengulangi analisis untuk memperoleh kurva kuantil bersyarat, termasuk regresi median, terhadap Data II, Data III, dan Data IV.

e. Penentuan model regresi median terbaik berdasarkan Mean Square Error (MSE) terkecil untuk tiap data (Data I sampai dengan Data IV).

\section{Perolehan Hasil dan Pembahasan}

Pada bagian ini akan dihasilkan analisis median pada copula yang terbaik untuk menjelaskan regresi median pada copula bivariat.

\section{HASIL DAN PEMBAHASAN}

\section{Data I}

Hasil pembangkitan bilangan acak untuk Data I diperoleh dari copula Plackett dengan $\theta=$ 2.4983501dan ditampilkan oleh scatterplot Gambar 1 .

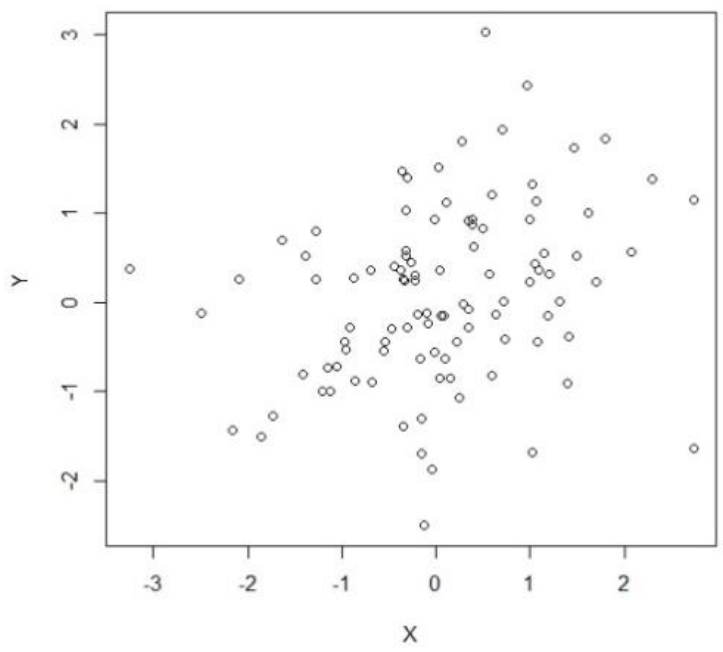

Gambar 1. Scatterplot Data I dalam $X$ dan $Y$

\section{a. Ukuran Keterhubungan Data I}

Ukuran keterhubungan digunakan untuk mengetahui arah hubungan antar dua peubah.Ukuran keterhubungan Kendall's tau, Spearman dan Pearson disajikan pada Tabel 1
Tabel 1. Korelasi Kendall's Tau, Spearman's Rho, Dan Korelasi Pearson Untuk Data I

\begin{tabular}{cccc}
\hline \multirow{2}{*}{$\begin{array}{c}\text { Sampel } \\
\text { Bivariat }\end{array}$} & \multicolumn{3}{c}{ Ukuran keterhubungan } \\
\cline { 2 - 4 } & $\begin{array}{c}\text { Kendall's } \\
\text { tau }\end{array}$ & $\begin{array}{c}\text { Spearman's } \\
\text { rho }\end{array}$ & $\begin{array}{c}\text { Korelasi } \\
\text { Pearson }\end{array}$ \\
\hline Data I & 0.218989 & 0.3125 & 0.282828 \\
\hline
\end{tabular}

Setelah diperoleh nilai keterhubungan, selanjutnya mencari nilai parameter pada setiap copula yang digunakan dalam penelitian ini. Hasil estimasi parameter copula disajikan pada Tabel 2

Tabel 2. Parameter Kendall's Tau, Spearman's Rho, Dan Korelasi Pearson Untuk Data I

\begin{tabular}{ccccc}
\hline \multirow{2}{*}{ Data } & \multicolumn{2}{c}{$\theta$} & $r$ & $\theta$ \\
\cline { 2 - 5 } & Frank & Clayton & Gaussian & Plackett \\
\hline Data I & 2.05154 & 0.5607863 & 0.282828 & 2.629903 \\
\hline
\end{tabular}

Berdasarkan hasil estimasi parameter Copula, perolehan $\theta$ pada copula Plackett tidak jauh berbeda dengan hasil pembangkitan data yaitu 2.629903.Maka dari itu dugaan awal untuk Data I adalah copula Plackett.

\section{b. Kurva Kuantil Bersyarat dan Median untuk Data I}

Pada bagian sebelumnya sudah diperoleh nilai parameter $\theta$ dari copula Plackett, maka selanjutnya akan dilakukan analisis kurva kuantil bersyarat. Analisis kurva kuantil bersyarat dilakukan untuk copula Plackett.Dari copula dipilih peubah-peubah yang mempunyai nilai Mean Square Error (MSE) terkecil. Untuk mengetahui kurva kuantil bersyarat mana yang mempunyai nilai Mean Square Error (MSE) terkecil maka akan dianalisis dengan menggunakan ukuran Mean Square Error (MSE).

Tabel 3. Nilai Mse Dari Regresi Median Pada Setiap Copula Dari Data I

\begin{tabular}{cc}
\hline \multirow{2}{*}{ Jenis Copula } & MSE $(\hat{y})$ \\
\cline { 2 - 2 } & Data I \\
\hline Gaussian & 0.8866 \\
\hline Frank & 0.8658 \\
\hline Clayton & 0.9875 \\
\hline Plackett & 0.8650 \\
\hline
\end{tabular}

Berdasarkan hasil perhitungan nilai Mean Square Error( $\hat{y})$ diperoleh bahwa kurva kuantil bersyarat yang terbaik dari Data I adalah copula Plackett karena memiliki nilai Mean Square Error $(\hat{y})$ terkecil dibandingkan dengan jenis copula yang lainnya dapat dilihat pada Tabel 3.Sehingga dapat dikatakan bahwa kurva kuantil bersyarat dari Data I memiliki kurva kuantil bersyarat terbaik yaitu copula Plackett. 


\section{Data II}

Hasil pembangkitan bilangan acak untuk Data II diperoleh dari copula Gaussian dengan $\rho=$ -0.7550955 dan ditampilkan oleh scatterplot Gambar 2.

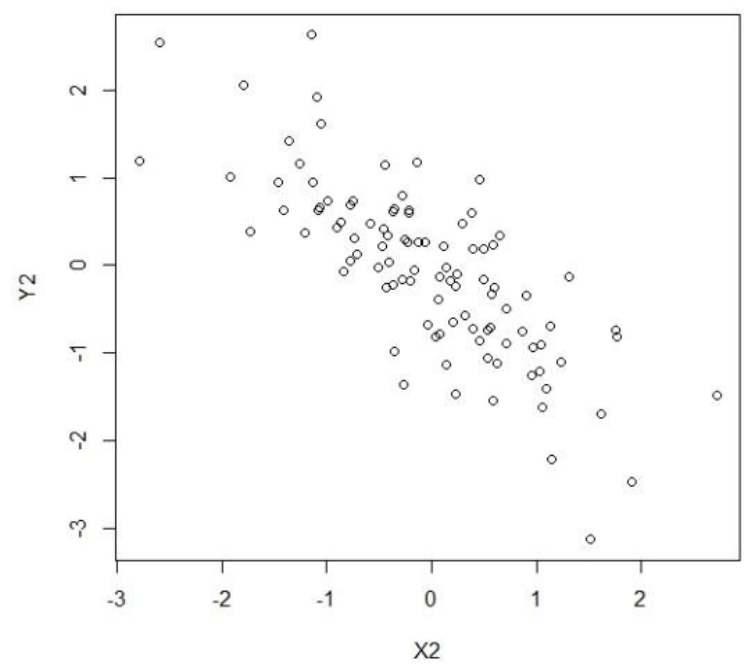

Gambar 2.Scatterplot Data II dalam $X$ dan $Y$

\section{a. Ukuran Keterhubungan Data II}

Ukuran keterhubungan digunakan untuk mengetahui arah hubungan antar dua peubah.Ukuran keterhubungan Kendall's tau, Spearman dan Pearson disajikan pada Tabel 4

Tabel 4. Korelasi Kendall's Tau, Spearman's Rho, dan Korelasi Pearson Untuk Data Ii

\begin{tabular}{cccc}
\hline \multirow{2}{*}{ Sampel } & \multicolumn{3}{c}{ Ukuran Keterhubungan } \\
\cline { 2 - 4 } Bivariat & $\begin{array}{c}\text { Kendall's } \\
\text { tau }\end{array}$ & $\begin{array}{c}\text { Spearman's } \\
\text { rho }\end{array}$ & $\begin{array}{c}\text { Korelasi } \\
\text { Pearson }\end{array}$ \\
\hline Data II & -0.5947475 & -0.7851425 & -0.7732132 \\
\hline
\end{tabular}

Setelah diperoleh nilai keterhubungan, selanjutnya mencari nilai parameter pada setiap copula yang digunakan dalam penelitian ini. Hasil estimasi parameter copula disajikan pada Tabel 5

Tabel 5. Parameter Kendall's Tau, Spearman's Rho, dan Korelasi Pearson Untuk Data II

\begin{tabular}{|c|c|c|c|c|}
\hline \multirow{2}{*}{ Data } & \multicolumn{2}{|c|}{$\theta$} & \multirow{2}{*}{$\frac{r}{\text { Gaussian }}$} & \multirow{2}{*}{$\begin{array}{c}\theta \\
\text { Plackett }\end{array}$} \\
\hline & Frank & Clayton & & \\
\hline Data II & -7.791 & -0.746 & -0.773 & 0.046 \\
\hline
\end{tabular}

Berdasarkan hasil estimasi parameter Copula, perolehan $r$ pada copula Gaussian tidak jauh berbeda dengan hasil pembangkitan data yaitu -0.773.Maka dari itu dugaan awal untuk Data II adalah copula Gaussian.

\section{b. Kurva Kuantil Bersyarat dan Median untuk Data II}

Pada bagian sebelumnya sudah diperoleh nilai parameter $\theta$ dari copula Gaussian, maka selanjutnya akan dilakukan analisis kurva kuantil bersyarat. Analisis kurva kuantil bersyarat dilakukan untuk copula Gaussian.Dari copula dipilih peubah-peubah yang mempunyai nilai Mean Square Error(MSE) terkecil. Untuk mengetahui kurva kuantil bersyarat mana yang mempunyai nilai Mean Square Error(MSE) terkecil maka akan dianalisis dengan menggunakan ukuran Mean Square Error (MSE).

Tabel 6. Nilai Mse Dari Regresi Median Pada Setiap Copula Dari Data II

\begin{tabular}{cc}
\hline \multicolumn{2}{c}{ Pada Setiap Copula Dari Data II } \\
\cline { 2 - 2 } Jenis Copula & MSE $(\hat{y})$ \\
\hline Gaussian & Data II \\
\hline Frank & 0.3954 \\
\hline Clayton & 0.4062 \\
\hline Plackett & 0.4259 \\
\hline
\end{tabular}

Berdasarkan hasil perhitungan nilai Mean Square Error (MSE)diperoleh bahwa kurva kuantil bersyarat yang terbaik dari Data II adalah copula Gaussian karena memiliki nilai Mean Square Error(MSE) ( $\hat{y}$ )terkecil dibandingkan dengan jenis copula yang lainnya dapat dilihat pada Tabel 6.Sehingga dapat dikatakan bahwa kurva kuantil bersyarat dari Data II memiliki kurva kuantil bersyarat terbaik yaitu copula Gaussian.

\section{Data III}

Hasil pembangkitan bilangan acak untuk Data III diperoleh dari copula Frank dengan $\theta=5.5843116 \mathrm{dan}$ ditampilkan oleh scatterplot Gambar 3.

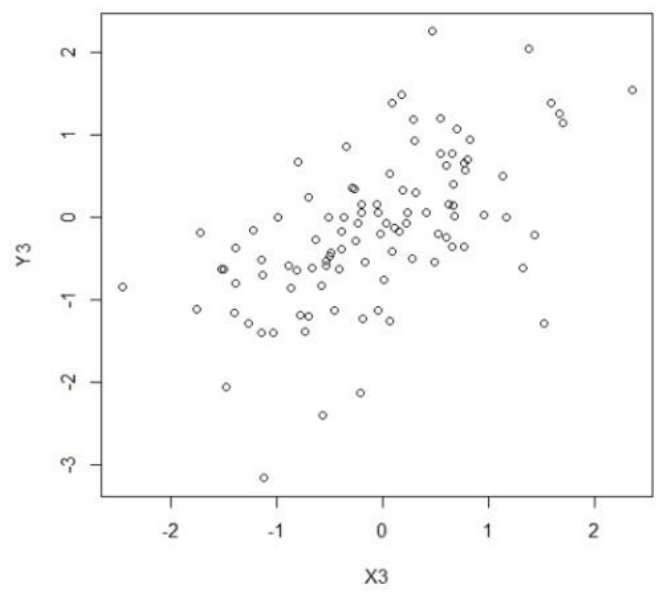

Gambar 3.Scatterplot Data III dalam $X$ dan $Y$

\section{a. Ukuran Keterhubungan Data III}

Ukuran keterhubungan digunakan untuk mengetahui arah hubungan antar dua peubah.Ukuran keterhubungan Kendall's tau, Spearman dan Pearson disajikan pada Tabel 7 
Tabel 7. Korelasi Kendall's Tau, Spearman's Rho, dan Korelasi Pearson Untuk Data III

\begin{tabular}{cccc}
\hline \multirow{2}{*}{ Sampel } & \multicolumn{3}{c}{ Ukuran Keterhubungan } \\
\cline { 2 - 4 } Bivariat & $\begin{array}{c}\text { Kendall's } \\
\text { tau }\end{array}$ & $\begin{array}{c}\text { Spearman's } \\
\text { rho }\end{array}$ & $\begin{array}{c}\text { Korelasi } \\
\text { Pearson }\end{array}$ \\
\hline Data III & 0.435 & 0.617 & 0.575 \\
\hline
\end{tabular}

Setelah diperoleh nilai keterhubungan, selanjutnya mencari nilai parameter pada setiap copula yang digunakan dalam penelitian ini. Hasil estimasi parameter copula disajikan pada Tabel 8

Tabel 8. Parameter Kendall's Tau, Spearman's Rho, dan Korelasi Pearson Untuk Data III

\begin{tabular}{ccccc}
\hline \multirow{2}{*}{ Data } & \multicolumn{2}{c}{$\theta$} & $r$ & $\theta$ \\
\cline { 2 - 5 } & Frank & Clayton & Gaussian & Plackett \\
\hline Data III & 4.660 & 1.538 & 0.575 & 8.375 \\
\hline
\end{tabular}

Berdasarkan hasil estimasi parameter Copula, perolehan $\theta$ pada copula Frank tidak jauh berbeda dengan hasil pembangkitan data yaitu 4.660. Maka dari itu dugaan awal untuk Data III adalah copula Frank.

\section{b. Kurva Kuantil Bersyarat dan Median untuk Data III}

Pada bagian sebelumnya sudah diperoleh nilai parameter $\theta$ dari copula Frank, maka selanjutnya akan dilakukan analisis kurva kuantil bersyarat. Analisis kurva kuantil bersyarat dilakukan untuk copula Frank. Dari copula dipilih peubah-peubah yang mempunyai nilai Mean Square Error (MSE)terkecil. Untuk mengetahui kurva kuantil bersyarat mana yang mempunyai nilai Mean Square Error (MSE)terkecil maka akan dianalisis dengan menggunakan ukuran Mean Square Error (MSE).

Tabel 9. Nilai Mse Dari Regresi Median Pada Setiap Copula Dari Data III

\begin{tabular}{cc}
\hline \multirow{2}{*}{ Jenis Copula } & MSE $(\hat{y})$ \\
\cline { 2 - 2 } & Data III \\
\hline Gaussian & 0.5708 \\
\hline Frank & 0.5575 \\
\hline Clayton & 0.6001 \\
\hline Plackett & 0.5634 \\
\hline
\end{tabular}

Berdasarkan hasil perhitungan nilai Mean Square Error (MSE)diperoleh bahwa kurva kuantil bersyarat yang terbaik dari Data III adalah copula Frank karena memiliki nilai Mean Square Error(MSE) $(\hat{y})$ terkecil dibandingkan dengan jenis copula yang lainnya dapat dilihat pada Tabel 9.Sehingga dapat dikatakan bahwa kurva kuantil bersyarat dari Data
III memiliki kurva kuantil bersyarat terbaik yaitu copula Frank.

\section{Data IV}

Hasil pembangkitan bilangan acak untuk Data IV diperoleh dari copula Clayton dengan $\theta=2.8233725$ dan ditampilkan oleh scatterplot Gambar 4.

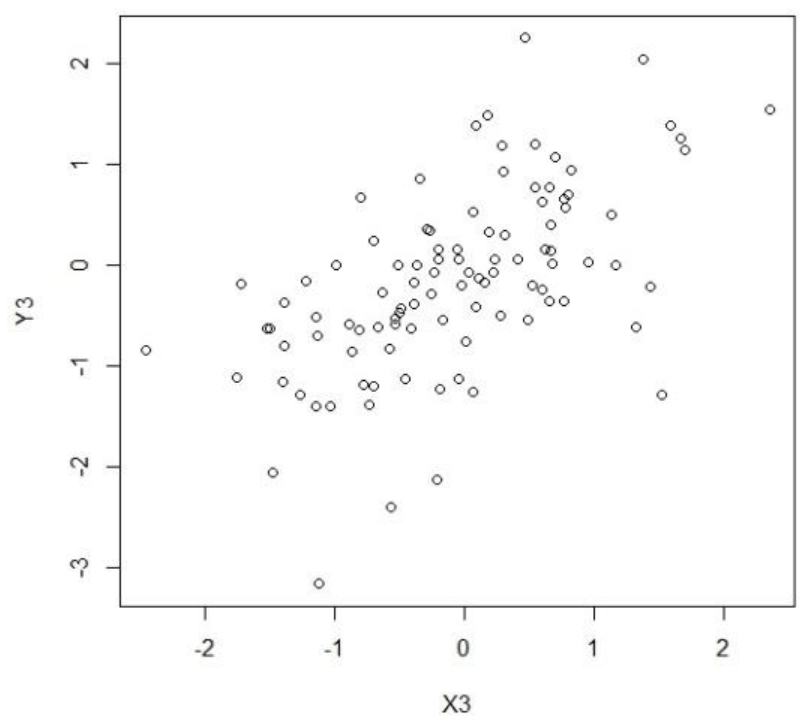

Gambar 4.Scatterplot Data IV dalam $X$ dan $Y$

\section{a. Ukuran Keterhubungan Data IV}

Ukuran keterhubungan Korelasi Kendall's Tau, Spearman's Rho, dan Pearson disajikan pada Tabel 10.

Tabel 10. Korelasi Kendall's Tau, Spearman's Rho, dan Korelasi Pearson Untuk Data IV

\begin{tabular}{cccc}
\hline Sampel & \multicolumn{3}{c}{ Ukuran keterhubungan } \\
\cline { 2 - 4 } Bivariat & Kendall's tau & Spearman's rho & Pearson \\
\hline Data IV & 0.534 & 0.702 & 0.746 \\
\hline
\end{tabular}

Setelah diperoleh nilai keterhubungan, selanjutnya mencari nilai parameter pada setiap copula yang digunakan dalam penelitian ini.Hasil estimasi parameter copula disajikan pada Tabel 11.

Tabel 11. Parameter Kendall's Tau, Spearman's Rho, dan Korelasi Pearson Untuk Data IV

\begin{tabular}{ccccc}
\hline \multirow{2}{*}{ Data } & \multicolumn{2}{c}{$\theta$} & $r$ & $\theta$ \\
\cline { 2 - 5 } & Frank & Clayton & Gaussian & Plackett \\
\hline Data IV & 6.386 & 2.289 & 0.746 & 12.869 \\
\hline
\end{tabular}

Berdasarkan hasil estimasi parameter Copula, perolehan $\theta$ pada copula Clayton tidak jauh berbeda dengan hasil pembangkitan data yaitu 2.289428. Maka dari itu dugaan awal untuk Data IV adalah copula Clayton.

a. Kurva Kuantil Bersyarat dan Median untuk Data IV

Pada bagian sebelumnya sudah diperoleh nilai parameter $\theta$ dari copula Clayton, maka selanjutnya 
akan dilakukan analisis kurva kuantil bersyarat. Analisis kurva kuantil bersyarat dilakukan untuk copula Clayton.Dari copula dipilih peubah-peubah yang mempunyai nilai Mean Square Error (MSE)terkecil. Untuk mengetahui kurva kuantil bersyarat mana yang mempunyai nilai Mean Square Error (MSE)terkecil maka akan dianalisis dengan menggunakan ukuran Mean Square Error (MSE).

Tabel 12. Nilai MSE Dari Regresi Median Pada Setiap Copula Dari Data IV

\begin{tabular}{cc}
\hline \multirow{2}{*}{ Jenis Copula } & MSE $(\hat{y})$ \\
\cline { 2 - 2 } & Data IV \\
\hline Gaussian & 0.3602 \\
\hline Frank & 0.3818 \\
\hline Clayton & 0.3190 \\
\hline Plackett & 0.3720 \\
\hline
\end{tabular}

Berdasarkan hasil perhitungan nilai Mean Square Error (MSE)diperoleh bahwa kurva kuantil bersyarat yang terbaik dari Data IV adalah copula Clayton karena memiliki nilai Mean Square Error(MSE) $(\hat{y})$ terkecil dibandingkan dengan jenis copula yang lainnya dapat dilihat pada Tabel 12.Sehingga dapat dikatakan bahwa kurva kuantil bersyarat dari Data IV memiliki kurva kuantil bersyarat terbaik yaitu copula Clayton.

\section{E. SIMPULAN DAN SARAN}

Beberapa hal yang dapat ditarik kesimpulan dalam penelitian ini adalah keterhubungan dua peubah acak yang diukur melalui Kendall's tau, Spearman's rho, dan korelasi Pearson dapat menentukan parameter copula.Model copula dapat diperoleh melalui uji kecocokan ukuran statistik Cramer von Misses $\left(S_{n}\right)$ berdasarkan $p_{\text {value }}$ melalui simulasi parametric bootsrap.Melalui properti bersyarat copula dapat ditentukan kurva kuantil dan regresi median untuk setiap copula.Kurva kuantil bersyarat terbaik yang terpilih berdasarkan nilai Mean Square Error(MSE) yang terkecil untuk Data I yaitu model copula Plackett sebesar 0,8650. Sedangkan nilai Mean Square Error(MSE)terkecil untuk Data II yaitu model copula Gaussian sebesar 0,3954. Nilai Mean Square Error(MSE)terkecil untuk Data III yaitu pada model copula Frank sebesar 0,5575. Terakhir, nilai Mean Square Error(MSE)terkecil untuk Data IV yaitu model copula Clayton sebesar 0,3190.

Dalam penelitian ini hanya membahas lima jenis copula, padahal saat ini sudah terdapat puluhan jenis copula dengan karakteristik yang berbeda. Mungkin dalam penelitian yang lain dilakukan pengembangan dengan diperluas penggunaan jenis copula.

\section{UCAPAN TERIMA KASIH}

Penulis mengucapkan terima kasih kepada Bapak Leopoldus Ricky Sasongko, M.Si dan Bapak Dr. Bambang Susanto, MS selaku Pembimbing yang telah memberikan banyak waktu, bantuan dan bimbingan.

\section{REFERENSI}

Arisandi, N.L., Nugroho, D.B., dan Sasongko, L.R. (2018). Analisis Prediktif Berdasarkan Kurs Beli IDR-USD Melalui Regresi Copula, Jurnal Matematika dan Aplikasi deCartesian, 7(2).

Bernard, C and Czado, C. (2014). Conditional Quantiles and Tails Dependence.Journal Education and Behavior Stattistic, 2(1), 8-12.

Bertsekas DP, Tsitsiklis JN. (2008). Introduction to Probability $1^{\text {nd }}$ Edition. New York: Athena Scientific.

Bhat, C.R and Eluru, N. (2009). Procedure to Generate Uniform Random Variates from Each Copula. Austin:University Station.

Luxviantono, E., Mahatma, T., dan Sasongko, L.R. (2018). Analisis Hubungan IHK (Indeks Harga Konsumen) dan Kurs Beli IDR-USD Melalui Pendekatan Copula. Jurnal Cartesian, 7(2).

Nelsen, R.B. (2006): An Introduction to Copulas $2^{\text {nd }}$ Edition, New York: Springer Series in statistics USA.

Sasongko, L.R. (2014).Copula Untuk Memodelkan Kegagalan Dua Dimensi pada Produk Bergaransi dengan Strategi Penggantian. Tesis, Institut Teknologi Bandung

Tse, Y.K. (2009): Nonlife Actuarial Models: Theory, Methods \& Evaluation, Cambridge Univesity Press.

Uthami, I.A.P, Sukarsa, I.G.K, dan Kencana, I.P.E.N. (2013). Regresi Kuantil Median untuk Mengatasi Heteroskedastisitas Pada Analisis Regresi. e-Jurnal Matematika,2(1). 